\title{
FAKTOR-FAKTOR PENGAMBILAN KEPUTUSAN PEMBELIAN BATIK DI TULUNGAGUNG
}

\author{
Sri Eka Astutiningsih \\ Email : srieka_astutiningsih@yahoo.com
}

\begin{abstract}
Abstrak : Tulisan ini bertujuan untuk mengkaji hubungan antara variabel marketing mix terhadap variabel keputusan pembelian.. Penelitian ini dilakukan pada 2 perusahaan batik di Tulungagung. Sampel diambil secara accidental sampling. Analisis data menggunakan regresi linier berganda. Hasil penelitian menunjukkan bahwa Berdasarkan hasil hasil Uji t pada dua lokasi perusahaan batik tersebut maka dapat diketahui bahwa secara parsial variabel marketing mix pada PB Gajah Mada memberikan pengaruh yang lebih signifikan dibanding dengan PB Satrio Manah, hal itu bisa dilihat dari 3 variabel berbanding 2 variabel antara PB Gajah Mada dan Satrio Manah. sedangkan uji $\mathrm{F}$ (simultan) menunjukkan bahwa variabel Produk (X1), Harga (X2), Promosi (X3), dan Tempat (X4) secara bersama-sama mempunyai pengaruh yang signifikan keputusan pembelian pada Perusahaan Batik seperti pada hipotesis kelima. Hal tersebut menunjukkan bahwa faktor Produk, Harga, Promosi dan Tempat merupakan faktor yang menjadi pertimbangan bagi konsumen sebelum melakukan pembelian.
\end{abstract}

Kata kunci : Marketing Mix, Keputusan Pembelian, Batik

\section{PENDAHULUAN}

Kebutuhan manusia seiring dengan perkembangan ilmu pengetahuan dan teknologi saat ini tentunya makin beragam, mulai dari kebutuhan makanan, tempat tinggal. Kebutuhan sandang saat ini merupakan gaya hidup seseorang Salah satu produk sandang karya khas daerah berupa batik. Batik bukan hanya diminati di dalam negeri, melainkan sudah membudaya hingga ke luar Indonesia, Pakaian batik menjadi ciri khas Indonesia dengan berbagai mode dari kalangan anak-anak, remaja, dewasa, bahkan lansia.

Batik di wilayah Tulungagung memiliki ciri khas dibanding dengan batik dari daerah lainnya. Pesona Batik Tulungagung terletak pada tingkat keberanian memadukan warna untuk menghasilkan batik dengan warna yang berbeda dari batik lainnya yang kebanyakan berwarna coklat maupun hitam. Batik Tulungagung lebih berani memadukan warna yang lebih cerah. Saat ini motif Batik Tulungagung memiliki 86 motif yang beraneka ragam dengan penggunaan berbagai segmen. Ragam motif menjadikan Batik Tulungagung berkembang tidak hanya melayani pasar lokal namun sudah mampu mengekspor sampai manca negara.

Sukses atau tidaknya produksi fashion oleh masyarakat berkaitan dengan kemampuan memasarkan dan mengenalkan produk. Pemasaran adalah suatu sistem keseluruhan dari kegiatan bisnis yang ditujukan untuk merencanakan, menentukan

Sri Eka Astutiningsih, adalah Dosen Prodi Perbankan Syariah FEBI IAIN Tulungagung 
harga, mempromosikan, dan mendistribusikan barang dan jasa yang memuaskan kebutuhan baik kepada pembeli yang ada maupun pembeli potensial (Swasta, 2000). Pada pengertian tersebut dapat kita mengerti bahwa kegiatan pemasaran itu mencakup kegiatan-kegiatan perusahaan yang dimulai dari penentuan harga, kegiatan promosi dan dan pendistribusian barang, keempat macam kegiatan tersebut sering disebut Marketing Mix atau Bauran pemasaran.

Bauran pemasaran merupakan salah satu strategi pemasaran untuk menyampaikan informasi secara luas, memperkenalkan suatu produk barang dan jasa, merangsang konsumen untuk membeli bahkan menciptakan preferensi pribadi terhadap image suatu produk. Oleh karena itu bauran pemasaran dianggap sebagai salah satu unsur strategi yang paling potensial didalam memasarkan produk. Strategi bauran pemasaran yaitu: produk, harga, promosi dan tempat sangat berperan terutama pada keadaan persaingan yang semakin tajam dan perkembangan akan permintaan barang. Dalam konteks ini perlu dianalisis lebih jauh hal-hal yang menjadikan keputusan konsumen dalam memilih produk sandang yang dikaitkan dengan bauran pemasaran yang dilakukan oleh produsen.

Lokasi penelitian yang dipilih yaitu Perusahaan Batik di Kabupaten Tulungagung, peneliti mengambil lokasi tersebut karena perusahaan batik Tulungagung cukup terkenal, memiliki outlet dan pasar yang luas serta letaknya yang strategis di Tulungagung. Berdasarkan uraian latar belakang diatas, peneliti tertarik untuk melakukan penelitian terkait dengan perilaku pembelian konsumen dengan judul Analisis Marketing Mix Terhadap Keputusan Pembelian Konsumen Di Perusahaan Batik Tulungagung. Fokus penulisan paper ini terkait dengan:

1. Adakah Marketing Mix berpengaruh signifikan terhadap keputusan pembelian konsumen di Perusahaan Batik Gajah Mada Kabupaten Tulungagung?

2. Adakah Marketing Mix berpengaruh signifikan terhadap keputusan pembelian konsumen di Perusahaan Satrio Manah Kabupaten Tulungagung?

3. Adakah penggunaan Marketing Mix dari kedua lokasi tersebut yang memiliki pengaruh paling signifikan secara simultan terhadap keputusan pembelian konsumen di Perusahaan Batik Kabupaten Tulungagung (PB. Gajah Mada dan PB Satrio Manah)?

\section{TINJAUAN PUSTAKA}

\section{Marketing Mix}

Kotler (2000) mendefinikan manajemen pemasaran sebagai suatu seni dan ilmu memilih pasar sasaran dan mendapatkan, menjaga, dan menumbuhkan pelanggan dengan menciptakan, menyerahkan dan mengkomunikasikan nilai pelanggan yang unggul (Rinto, 2012). Keberhasilan suatu perusahaan berdasarkan keahliannya dalam mengendalikan strategi pemasaran yang dimiliki.Konsep pemasaran mempunyai seperangkat alat pemasaran yang sifatnya dapat dikendalikan yaitu yang lebih dikenal dengan marketing mix (bauran pemasaran).

Kotler (2004) memberikan definisi mengenai bauran pemasaran sebagai: Bauran pemasaran adalah perangkat alat pemasaran faktor yang dapat dikendalikan product, price, promotions, place yang dipadukan oleh perusahaan untuk menghasilkan respon yang diinginkan dalam pasar sasaran 


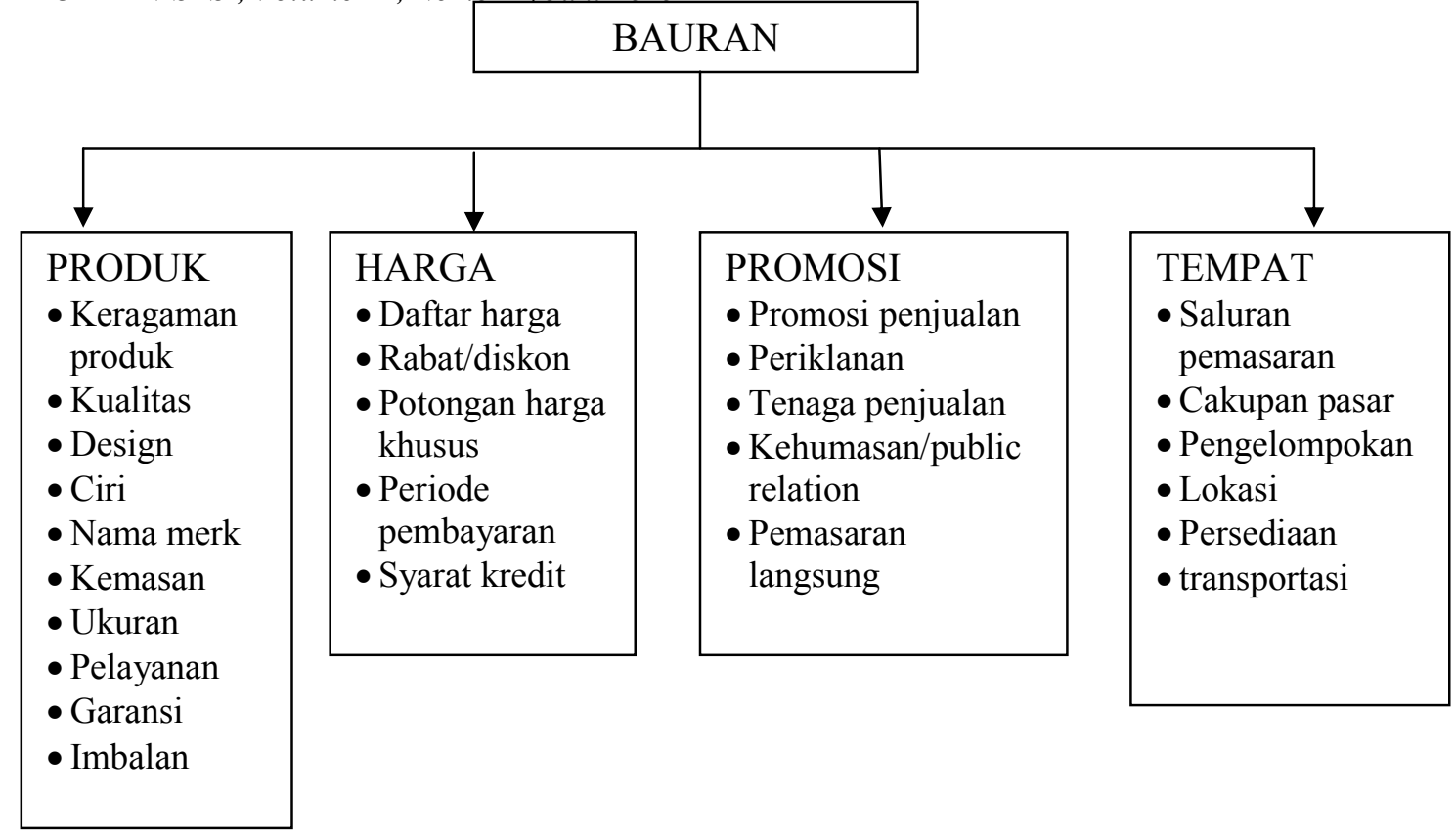

Sumber: Kotler dan Armstrong, 2004,

Gambar 1. Komponen 4P dari Marketing Mix

\section{Product (Produk)}

Produk merupakan elemen penting dalam sebuahprogram pemasaran. Strategi produk dapat mempengaruhi strategi pemasaran lainnya.Pembelian sebuah produk bukan hanya sekedar untuk memiliki produk tersebut tetapi juga untuk memenuhi kebutuhan dan keinginan konsumen (Rianto, 2012). Menurut Kotler (2004) Produk adalah segala sesuatu yang dapat ditawarkan ke suatu pasar untuk memenuhi keinginan dan kebutuhan. Bagian-bagian dari produk meliputi: Keragaman produk, Kualitas, Design, Ciri, Nama merek, Kemasan, Ukuran, Pelayanan, Garansi, Imbalan.

\section{Price (Harga)}

Pada setiap produk atau jasa yang ditawarkan, bagian pemasaran dapat menentukan harga produk dan harga jual suatu produk. Faktor-faktor yang perlu dipertimbangkan dalam suatu penetapan harga antara lain biaya, keuntungan, harga yang ditetapkan oleh pesaing dan perubahan keinginan pasar (Rianto, 2012). Bagian-bagian dari harga meliputi: Daftar harga, Rabat/diskon, Potongan harga khusus, Periode pembayaran, Syarat kredit

\section{Promotions (Promosi)}

Promosi merupakan komponen yang dipakai utuk memberitahukan dan mempengaruhi pasar bagi produk perusahaan, sehingga pasar dapat mengetahui tentang produk yang diproduksikan oleh perusahaan tersebut. Adapun kegiatan yang termasuk dalam aktivitas promosi adalah periklanan, personal selling, promosi penjualan, dan publisitas. Promosi di sini terkait dengan besaran biaya promosi dan kegiatan promosi yang akan dilakukan. Tujuan yang diharapkan dari promosi adalah konsumen dapat mengetahui tentang produk tersebut dan pada akhirnya memutuskan untuk membeli produk tersebut (Rianto, 2012). Bagian- 
bagian dari promosi yaitu: Promosi penjualan, Periklanan, Tenaga penjualan, Kehumasan/public relation, Pemasaran langsung.

\section{Place (Tempat)}

Yang perlu diperhatikan dari keputusan mengenai tempat yaitu:

1) Sistem transportasi perusahaan

2) Sistem penyimpanan

3) Pemilihan saluran distribusi

Termasuk dalam sistem transportasi antara lain keputusan tentang pemilihan alat transportasi, penentuan jadwal pengiriman, rute yang harus ditempuh dan seterusnya. Dalam sistem penyimpanan, harus menentukan letak gudang baik untuk untuk menyimpan bahan baku maupun lokasi untuk penyimpanan barang jadi, jenis peralatan yang digunakan untuk mengenai material maupun peralatan lainnya. Sedangkan pemilihan saluran distribusi menyangkut keputusan tentang penggunaan penyalur (pedagang besar, pengecer, agen, makelar) dan bagaimana menjalin kerjasama yang baik dengan para penyalur (Rianto, 2012).

\section{Keputusan Pembelian}

Menurut Lamb dkk (2001), proses pengambilan keputusan konsumen adalah proses tahap demi tahap yang digunakan konsumen ketika membeli barang atau jasa. Sedangkan Kerin dkk (2004) mengemukakan bahwa Proses keputusan pembelian adalah tingkatan seorang pembeli yang telah siap dalam membuat pilihan mengenai produk dan jasa yang akan dibeli). Secara umum, konsumen memiliki 5 (lima) tahap untuk mencapai suatu keputusan pembelian yang disebut sebagai tahapan penelitian, yaitu (Angipora, 1999):

Tahap Pengenalan Masalah

Proses pembelian dimulai ketika pembeli mengenal suatu masalah atau kebutuhan yang dipicu oleh stimuli internal (lapar, haus, dst) atau eksternal (melihat iklan rekreasi ke Hawai). Pada tahap ini konsumen mengenali sebuah kebutuhan, keinginan atau masalah.

Tahap Pencarian Informasi

Hal-hal yang paling penting untuk diketahui oleh perusahaan adalah sumber informasi utama yang akan digunakan oleh konsumen dan pengaruhnya terhadap keputusan pembelian kemudian (Kotler, 2000).

Tahap Evaluasi Alternatif/Pilihan

Setelah mendapat informasi dari sumber-sumber di atas, maka tahap selanjutnya adalah bagaimana konsumen menggunakan informasi tersebut untuk tiba pada satu pilihan merk akhir dan bagaimana konsumen memilih di antara merk-merk alternatif.

Tahap Keputusan Pembelian

Pada tahap ini, konsumen membentuk pilihan dan menetapkan pilihannya berdasarkan pertimbangan merek, penyalur, kuantitas, waktu, dan metode pembayaran. 
Tahap Perilaku Sesudah Pembelian

Tugas perusahaan pada dasarnya tidak hanya berakhir setelah konsumen membeli produk yang dihasilkan, tetapi yang harus diperhatikan lebih lanjut adalah meneliti dan memonitor apakah konsumen akan mengalami tingkat kepuasan atau ketidakpuasan setelah menggunakan produk yang dibeli.

\section{Penelitian Terdahulu}

Studi penelitian yang dilakukan oleh Selang (2013), bertujuan untuk mengetahui bauran pemasaran (marketing mix) pengaruhnya terhadap loyalitas konsumen pada fresh mart bahu mall manado, yang terdiri dari produk, harga, promosi dan distribusi, yang didalamnya akan menentukan tingkat keberhasilan pemasaran dan semua itu ditujukan untuk mendapatkan respon yang diinginkan dari pasar sasaran. metode pengambilan sampel yang digunakan berdasarkan teknik non probability yaitu purposive Sampling, dimana sampel dipilih secara sengaja dan metode analisis yang digunakan adalah analisis regresi linear berganda. Hasil penelitian menunjukkan bahwa secara parsial produk, harga berpengaruh signifikan terhadap loyalitas konsumen dan promosi, tempat tidak berpengaruh signifikan terhadap loyalitas konsumen.Secara Simultan produk, harga, promosi dan tempat berpengaruh signifikan terhadap Loyalitas Konsumen.Mengingat promosi dan tempat memiliki pengaruh yang lemah terhadap loyalitas konsumen, maka sebaiknya managemen memperhatikan dan meningkatkan peran dari promosi dan pemilihan tempat dalam perencanaan pemasaran perusahan.

Studi yang dilakukan oleh Yulianto dkk (2010), bertujuan untuk menganalisis pengaruh faktor bauran pemasaran (marketing mix) yang terdiri dari produk, harga, promosi, tempat/lokasi, pelayanan pegawai, proses pelayanan, dan bentuk fisik bank syariah. Selain itu juga untuk menginformasikan faktor yang paling dominan dari ketujuh faktor tersebut.Penelitian ini merupakan penelitian kuantitatif dan deskriptif, yaitu menjelaskan pengaruh faktor bauran pemasaran dilihat dari sudut pandang konsumen terhadap pertimbangan nasabah dalam memilih bank syariah. Populasi dalam penelitian ini adalah para nasabah, khususnya nasabah perorangan dari PT. Bank Syariah Mandiri, PT. Bank BNI Syariah, dan PT. Bank Muamalat Indonesia di kota Medan. Jumlah sampel sebanyak 100 responden.Sedangkan analisis datanya yaitu menggunakan regresi linier berganda. Hasil analisis menunjukkan bahwa faktor-faktor yang mempengaruhi pertimbangan nasabah dalam memilih bank syariah di kota Medan adalah produk, tempat/lokasi, dan pelayanan pegawai bank. Sedangkan faktor harga, promosi, proses, dan bentuk fisik bank tidak mempunyai pengaruh yang signifikan. Dari semua faktor tersebut, faktor produk merupakan faktor yang paling dipertimbangkan nasabah dalam memilih bank syariah di kota Medan.

Studi lain yaitu oleh Sukotjo dan Sumanto Radix A (2010) dengan judul "Analisa Marketing Mix-7P (Produk, Price, Promotion, Place, Partisipant, Process, dan Physical Evidence) terhadap Keputusan Pembelian Produk Klinik Kecantikan Teta di Surabaya". Penelitian ini bertujuan untuk mengetahui pengaruh yang signifikan secara simultan (bersama-sama) dan secara parsial antara variablevariabel dalam konsep marketing mix 7P yang terdiri dari : Produk, price, promosi, place (saluran distribusi), partisipant, physical evidence (lingkungan fisik), dan proses terhadap pengambilan keputusan pembelian produk Klinik kecantikan di Surabaya, serta Variabel manakah dari marketing mix-7P yang memiliki pengaruh paling dominan terhadap keputusan dalam pembelian produk klinik kecantikan di Surabaya. penelitian ini menggunakan pendekatan kuantitatif, dimana menitikberatkan pada pengujian hipotesis. Adapun jumlah responden yaitu sebesar 
115. Adapun hasil penelitiannya yaitu: pertama, secara bersama-sama konsep marketing mix 7P mempunyai pengaruh terhadap pengambilan keputusan pembelian produk Klinik kecantikan di Surabaya. Kedua, Variabel produk, harga, promosi, dan lokasi secara parsial berpengaruh terhadap Keputusan pembelian pada klinik kecantikan Teta.Ketiga, Dari ketujuh variable: produk, harga, promosi, lokasi, partisipant (beauty therapist, dokter dan receptionist), proses, dan lingkungan fisik. Variabel promosi adalah variabel yang paling dominan terhadap keputusan pembelian pada klinik kecantikan Teta di kota Surabaya.

Nikolas K. Papavassilio (2012), tentang "Pengaruh Model Pengiklanan Konsumen Terhadap Produk Luar Negeri" dalam jurnal ini berisi tentang faktor yang mempengaruhi tingkat keterlibatan konsumen salah satunya adalah pembeli, pembeli adalah target pemasukan yang secara terus menerus, maksudnya mempengaruhi pemilihan produk. Mereka para pembeli selektif dalam menerima informasi tentang berbagai produk dengan berbagia merek yang bersaing yang disediakan oleh penjual. Para penjual mengatur suatu jaringan asosiasi pengiklanan dan direspon baik untuk melayani permintaan pembeli sesuai informasi. Menurut Nikolas 6 faktor yang menentukan keterlibatan konsumen dalam informasi yaitu : produk, negara, konsumen, pasar, iklan dan medium iklan.

\section{Kerangka Berfikir}

Berdasarkan kajian teoritis dan kajian empiris diatas, dapat ditarik sebuah kerangka berfikir penelitian sebagai berikut :

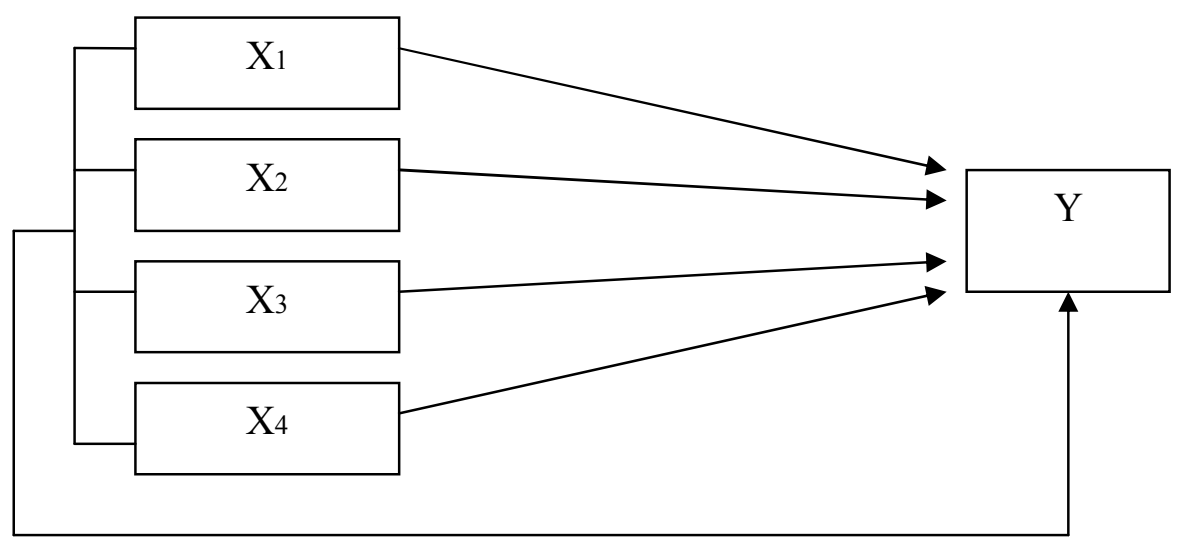

\section{Gambar 2. Kerangka Berfikir Penelitian}

Keterangan: $\mathrm{X} 1=$ Produk

$\mathrm{X} 2=$ Harga

$\mathrm{X} 3=$ Promosi

$\mathrm{X} 4=$ Tempat

$\mathrm{Y}=$ Keputusan pembelian Konsumen Pada Perusahaan Batik Tulungagung.

1. Hipotesis

Adapun hipotesis pada penelitian ini adalah : 


\section{MODERNISASI, Volume 11, Nomor 2, Juni 2015}

1. Ada pengaruh yang signifikan faktor produk terhadap keputusan pembelian batik di Perusahaan Batik Kabupaten Tulungagung.

2. Ada pengaruh yang signifikan faktor harga terhadap keputusan pembelian batik di Perusahaan Batik Kabupaten Tulungagung.

3. Ada pengaruh yang signifikan faktor promosi terhadap keputusan pembelian batik di Perusahaan Batik Kabupaten Tulungagung.

4. Ada pengaruh yang signifikan faktor tempat terhadap keputusan pembelian batik di Perusahaan Batik Kabupaten Tulungagung.

5. Ada pengaruh yang signifikan faktor produk, harga, promosi dan tempat secara simultan terhadap keputusan pembelian batik di Perusahaan Batik Kabupaten Tulungagung.

\section{METODE}

Jenis penelitian ini adalah kuantitatif yaitu penelitian yang bertujuan untuk mengetahui hubungan antara dua variabel atau lebih (Sugiono, 1999). Variabel yang digunakan dalam penelitian ini adalah: Variabel bebas $(\mathrm{X})$ yaitu, $\mathrm{X}_{1}=$ Produk, $\mathrm{X}_{2}=$ Harga, $\mathrm{X}_{3}=$ Promosi, $\mathrm{X}_{4}=$ Tempat. Variabel tergantung $(\mathrm{Y})$ yaitu, keputusan pembelian konsumen pada perusahaan batik Tulungagung.

Populasi dalam penelitian ini adalah pelanggan maupun pembeli batik di Tulungagung. Metode pengambilan sampel yang digunakan berdasarkan teknik non probability sampling yaitu accidential sampling, dimana pengunjung diambil secara kebetulan bila dipandang orang yang kebetulan ditemui itu cocok sebagai sumber data (Sugiono, 1999). Pada Perusahaan Batik di Tulunggung tidak terhitung berapa jumlah pengunjung karena transaksi pembelian masih sederhana dengan menggunakan nota pembelian, jika di kira-kira dalam satu bulan hampir 200 pembeli bagi perusahaan batik terbesar, tapi untuk yang sedang berkembang pembeli yang datang hanya sedikit, kebanyakan adalah melalui pesanan dalam jumlah besar yang dilakukan oleh lembaga pemerintah. Sesuai dengan pengambilan sampel accidentil maka batas minimal adalah 100 responden untuk masing-masing lokasi penelitian yaitu PB Gajah Mada dan PB Barong Gung.

Sumber data yang peneliti gunakan adalah sumber data primer yaitu dengan metode pengumpulan data berupa angket dengan prinsip pengukuran yang peneliti gunakan yaitu skala likert dimana skala tersebut digunakan untuk mengukur pengaruh Marketing Mix (produk, harga, promosi dan tempat) terhadap keputusan pembelian konsumen di Perusahaan Batik Tulungagung. Untuk memperoleh data yang diperlukan, maka ada beberapa metode yang peneliti pergunakan, yaitu: Metode Angket, Metode wawancara, Metode Dokumentasi, dan Metode Observasi (Arikunto, 2002; Hadi, 1987).

Teknik analisis data dalam penelitian ini menggunakan Uji Regresi Linear Berganda (Sudarmanto, 2005). 


\section{PEMBAHASAN}

\section{Analisa data}

\section{PB GAJAH MADA}

Table 1

Uji Regresi variabel Produk $\left(X_{1}\right)$, Harga $\left(X_{2}\right)$, Promosi $\left(X_{3}\right)$ dan Tempat $\left(X_{4}\right)$ terhadap Keputusan Pembelian (Y)

\begin{tabular}{|c|c|c|c|c|c|c|}
\hline \multicolumn{7}{|c|}{ Coefficients $^{\mathrm{a}}$} \\
\hline \multirow{2}{*}{\multicolumn{2}{|c|}{ Model }} & \multicolumn{2}{|c|}{ Unstandardized Coefficients } & \multirow{2}{*}{$\begin{array}{c}\begin{array}{c}\text { Standardized } \\
\text { Coefficients }\end{array} \\
\text { Beta }\end{array}$} & \multirow[b]{2}{*}{$\mathrm{t}$} & \multirow[b]{2}{*}{ Sig. } \\
\hline & & $\mathrm{B}$ & Std. Error & & & \\
\hline \multirow[t]{5}{*}{1} & (Constant) & .814 & .519 & & 1.570 & .120 \\
\hline & Produk & .246 & .110 & .213 & 2.237 & .028 \\
\hline & Harga & .056 & .077 & .065 & .723 & .472 \\
\hline & Promosi & .254 & .097 & .290 & 2.630 & .010 \\
\hline & Tempat & .289 & .133 & .242 & 2.174 & .032 \\
\hline
\end{tabular}

a. Dependent Variable: Keputusan_pembelian

Sumber: Lampiran 3, diolah

1. Untuk Untuk rumusan masalah yang pertama dengan hipotesis yang berbunyi "Produk berpengaruh signifikan terhadap Keputusan Pembelian Konsumen". Dalam tabel Coefficients diperoleh nilai Sig. sebesar 0,028 dibandingkan dengan taraf signifikansi $(\alpha=5 \%) 0,05$ maka:

$$
\text { Sig. }<\alpha=0,028<0,05
$$

Karena nilai Sig. $<\alpha$ maka disimpulkan untuk $\mathrm{H}_{0}$ ditolak, yang berarti ada pengaruh signifikan dari faktor Produk terhadap Keputusan Pembelian Konsumen di PB Gajah Mada Tulungagung

2. Untuk rumusan masalah yang pertama dengan hipotesis yang berbunyi "Harga berpengaruh signifikan terhadap Keputusan Pembelian Konsumen". Dalam tabel Coefficients diperoleh nilai Sig. sebesar 0,472 dibandingkan dengan taraf signifikansi $(\alpha=5 \%) 0,05$ maka:

$$
\text { Sig. }<\alpha=0,472>0,05
$$

Karena nilai Sig. $>\alpha$ maka disimpulkan untuk H0 diterima, yang berarti tidak ada pengaruh signifikan dari faktor Harga terhadap Keputusan Pembelian Konsumen di PB Gajah Mada Tulungagung.

3. Untuk rumusan masalah pertama dengan hipotesis yang berbunyi "Promosi berpengaruh signifikan terhadap Keputusan Pembelian Konsumen". Dalam 
MODERNISASI, Volume 11, Nomor 2, Juni 2015

tabel Coefficients diperoleh nilai Sig. sebesar 0,010 dibandingkan dengan taraf signifikansi $(\alpha=5 \%) 0,05$ maka:

$$
\text { Sig. }<\alpha=0,010<0,05
$$

Karena nilai Sig. $<\alpha$ maka disimpulkan untuk $\mathrm{H}_{0}$ ditolak, yang berarti ada pengaruh signifikan dari faktor Promosi terhadap Keputusan Pembelian Konsumen di PB Gajah Mada Tulungagung.

4. Untuk rumusan masalah pertama dengan hipotesis yang berbunyi "Tempat berpengaruh signifikan terhadap Keputusan Pembelian Konsumen". Dalam tabel Coefficients diperoleh nilai Sig. sebesar 0,032 dibandingkan dengan taraf signifikansi $(\alpha=5 \%) 0,05$ maka:

$$
\text { Sig. }<\alpha=0,032<0,05
$$

Karena nilai Sig. $<\alpha$ maka disimpulkan untuk H0 ditolak, yang berarti ada pengaruh signifikan dari faktor Tempat terhadap Keputusan Pembelian Konsumen di PB Gajah Mada Tulungagung.

Table 2

Hasil Analisis Uji F Variabel $\left(\mathrm{X}_{1}\right),\left(\mathrm{X}_{2}\right),\left(\mathrm{X}_{3}\right),\left(\mathrm{X}_{4}\right)$

\begin{tabular}{|c|c|c|c|c|c|c|}
\hline \multicolumn{2}{|c|}{ Model } & $\begin{array}{l}\text { Sum of } \\
\text { Squares }\end{array}$ & df & Mean Square & $\mathrm{F}$ & Sig. \\
\hline 1 & Regression & 12.917 & 4 & 3.229 & 15.215 & $.000^{\mathrm{a}}$ \\
\hline & Residual & 20.163 & 95 & .212 & & \\
\hline & Total & 33.080 & 99 & & & \\
\hline
\end{tabular}

ANOVA $^{\mathrm{b}}$

a. Predictors: (Constant), Tempat, Harga, Produk, Promosi

b. Dependent Variable: Keputusan_pembelian

Sumber: Lampiran 3, diolah

5. Untuk rumusan masalah yang ketiga dengan hipotesis yang berbunyi "Produk, Harga, Promosi dan Tempat secara bersama-sama berpengaruh signifikan terhadap Keputusan Pembelian Konsumen". Dalam tabel ANOVA diatas diperoleh nilai $\mathrm{F}$ hitung sebesar 15.215 dengan tingkat signifikai 0,000 dibandingkan dengan taraf signifikasi $(\alpha=5 \%)$ 0,05 maka:

$$
\text { sig. }<\alpha=0,000<0,05
$$

Karena nilai sig. $<\alpha$ maka disimpulkan untuk menolak $\mathrm{H}_{0}$, yang berarti faktor Produk, Harga, Promosi dan Tempat pada PB Gajah Mada berpengaruh signifikan terhadap Keputusan Pembelian Konsumen. 


\section{PB SATRIO MANAH}

Table 3

Uji Regresi variabel Produk $\left(X_{1}\right)$, Harga $\left(X_{2}\right)$, Promosi $\left(\mathbf{X}_{3}\right)$ dan Tempat $\left(\mathbf{X}_{4}\right)$ terhadap Keputusan Pembelian (Y) Coefficients $^{\mathrm{a}}$

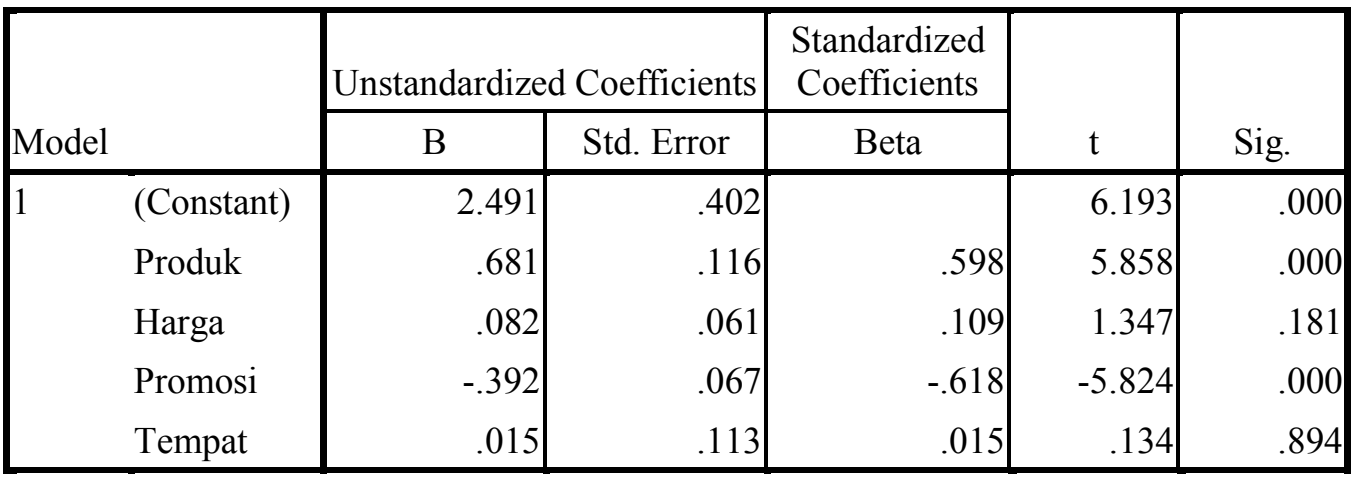

a. Dependent Variable: Keputusan_Pembelian

Sumber: Lampiran 3, diolah.

1. Untuk rumusan masalah yang kedua dengan hipotesis yang berbunyi "Produk berpengaruh signifikan terhadap Keputusan Pembelian Konsumen di PB Satrio Manah". Dalam tabel Coefficientsdiperoleh nilai Sig. sebesar 0,000 dibandingkan dengan taraf signifikansi $(\alpha=5 \%) 0,05$ maka:

$$
\text { Sig. }<\alpha=0,000<0,05
$$

Karena nilai Sig. $<\alpha$ maka disimpulkan untuk H0 ditolak, yang berarti ada pengaruh signifikan dari faktor Produk terhadap Keputusan Pembelian Konsumen di PB Satrio Manah Tulungagung

2. Untuk rumusan masalah yang kedua dengan hipotesis yang berbunyi "Harga berpengaruh signifikan terhadap Keputusan Pembelian Konsumen". Dalam tabel Coefficients diperoleh nilai Sig. sebesar 0,181 dibandingkan dengan taraf signifikansi $(\alpha=5 \%)$ 0,05 maka:

$$
\text { Sig. }<\alpha=0,181>0,05
$$

Karena nilai Sig. $>\alpha$ maka disimpulkan untuk H0 diterima, yang berarti tidak ada pengaruh signifikan dari faktor Harga berpengaruh signifikan terhadap Keputusan Pembelian Konsumen di PB Satrio Manah Tulungagung

3. Untuk rumusan masalah yang kedua dengan hipotesis yang berbunyi "Promosi berpengaruh signifikan terhadap Keputusan Pembelian Konsumen". Dalam tabel Coefficients diperoleh nilai Sig. sebesar 0,000 dibandingkan dengan taraf signifikansi $(\alpha=5 \%)$ 0,05 maka:

$$
\text { Sig. }<\alpha=0,000<0,05
$$


MODERNISASI, Volume 11, Nomor 2, Juni 2015

Karena nilai Sig. $<\alpha$ maka disimpulkan untuk H0 ditolak, yang berarti ada pengaruh signifikan dari faktor Promosi berpengaruh signifikan terhadap Keputusan Pembelian Konsumen di PB Satrio Manah Tulungagung.

4. Untuk rumusan masalah yang kedua dengan hipotesis yang berbunyi "Tempat berpengaruh signifikan terhadap Keputusan Pembelian Konsumen”. Dalam tabel Coefficientsdiperoleh nilai Sig. sebesar 0,894 dibandingkan dengan taraf signifikansi $(\alpha=5 \%)$ 0,05 maka:

$$
\text { Sig. }<\alpha=0,894>0,05
$$

Karena nilai Sig. $>\alpha$ maka disimpulkan untuk H0 ditterima, yang berarti tidak ada pengaruh signifikan dari faktor Tempat berpengaruh signifikan terhadap Keputusan Pembelian Konsumen di PB Satrio Manah Tulungagung.

Table 4

Hasil Analisis Uji F Variabel $\left(\mathrm{X}_{1}\right),\left(\mathrm{X}_{2}\right),\left(\mathrm{X}_{3}\right),\left(\mathrm{X}_{4}\right)$ ANOVA $^{b}$

\begin{tabular}{|ll|r|r|r|r|r|}
\hline \multicolumn{1}{|l|}{ Model } & \multicolumn{1}{|c|}{$\begin{array}{c}\text { Sum of } \\
\text { Squares }\end{array}$} & $\mathrm{df}$ & Mean Square & $\mathrm{F}$ & Sig. \\
\hline 1 & Regression & 5.828 & 4 & 1.457 & 16.448 & $.000^{\mathrm{a}}$ \\
& Residual & 8.416 & 95 & .089 & & \\
& Total & 14.244 & 99 & & & \\
\hline
\end{tabular}

a. Predictors: (Constant), Tempat, Harga, Produk, Promosi

b. Dependent Variable: Keputusan_Pembelian

Sumber: Lampiran 3, diolah

5. Untuk rumusan masalah yang ketiga dengan hipotesis yang berbunyi "Produk, Harga, Promosi dan Tempat secara bersama-sama berpengaruh signifikan terhadap Keputusan Pembelian Konsumen". Dalam tabel ANOVA diatas diperoleh nilai $F$ hitung sebesar 16.448 dengan tingkat signifikansi 0,000 dibandingkan dengan taraf signifikansi $(\alpha=5 \%) 0,05$ maka:

$$
\text { sig. }<\alpha=0,000<0,05
$$

Karena nilai sig. $<\alpha$ maka disimpulkan untuk menolak $\mathrm{H}_{0}$, yang berarti faktor Produk, Harga, Promosi dan Tempat di PB Satrio Manah berpengaruh signifikan terhadap Keputusan Pembelian Konsumen.

\section{Pembahasan hasil penelitian.}

Setelah peneliti melakukan penelitian secara langsung dengan menggunakan penyebaran angket yang diajukan kepada konsumen batik Tulungagung yaitu Perusahaan Batik Gajah Mada dan Perusahaan Batik Satrio Manah dan diisi oleh para konsumen. maka tujuan yang dikemukakan dalam penelitian ini adalah untuk mengetahui: 
a. Pengaruh Marketing Mix (Produk, harga, promosi dan tempat) terhadap keputusan pembelian konsumen di Perusahaan Batik Gajah Mada Kabupaten Tulungagung.

Hasil uji t pada regresi data penelitian menunjukkan bahwa:

1) variabel Produk mempunyai pengaruh positif dan signifikan terhadap keputusan pembelian konsumen Batik Gajah Mada dengan taraf signifikan $0,028<0,05$.

2) variabel Harga tidak mempunyai pengaruh positif dan signifikan terhadap keputusan pembelian konsumen Batik Gajah Mada dengan taraf signifikan 0,472>0,05.

3) variabel Promosi mempunyai pengaruh positif dan signifikan terhadap keputusan pembelian konsumen Batik Gajah Mada dengan taraf signifikan $0,010<0,05$.

4) variabel Tempat mempunyai pengaruh positif dan signifikan terhadap keputusan pembelian konsumen Batik Gajah Mada dengan taraf signifikan $0,032<0,05$.

sedangkan hasil uji $\mathrm{F}$ pada regresi data penelitian menunjukkan bahwa terdapat pengaruh yang signifikan secara simultan Marketing Mix (Produk, harga, promosi dan tempat) terhadap keputusan pembelian konsumen di Perusahaan Batik Gajah Mada Kabupaten Tulungagung dengan taraf signifikan $0,000<0,05$.

Hasil penelitian ini hampir sama dengan studi yang dilakukan oleh Hendri Sukotjo dan Sumanto Radix A, dengan judul "Analisa Marketing Mix-7P (Produk, Price, Promotion, Place, Partisipant, Process, dan Physical Evidence) terhadap Keputusan Pembelian Produk Klinik Kecantikan Teta di Surabaya. Dalam penelitian ini membandingkan diantara variabel yang paling signifikan antara ketujuh variabel, sedangkan dalam penelitian yang peneliti lakukan membandingkan signifikansi variabel dari dua lokasi perusahaan (Mubarok dan Puspitasari, 2010).

b. Pengaruh Marketing Mix (Produk, harga, promosi dan tempat) terhadap keputusan pembelian konsumen di Perusahaan Batik Satrio Manah Kabupaten Tulungagung

Hasil uji t pada regresi data penelitian menunjukkan bahwa:

1) variabel Produk mempunyai pengaruh positif dan signifikan terhadap keputusan pembelian konsumen Batik Satrio Manah dengan taraf signifikan $0,000<0,05$.

2) variabel Hargatidak mempunyai pengaruh positif dan signifikan terhadap keputusan pembelian konsumen Batik Satrio Manahdengan taraf signifikan $0,181>0,05$.

3) variabel Promosi mempunyai pengaruh positif dan signifikan terhadap keputusan pembelian konsumen Batik Satrio Manahdengan taraf signifikan $0,000<0,05$.

4) variabel Tempattidak mempunyai pengaruh positif dan signifikan terhadap keputusan pembelian konsumen Batik Satrio Manahdengan taraf signifikan 0,894 >0,05. 
Sedangkan hasil uji $\mathrm{F}$ pada regresi data penelitian menunjukkan bahwa terdapat pengaruh yang signifikan secara simultan Marketing Mix (Produk, harga, promosi dan tempat) terhadap keputusan pembelian konsumen di Perusahaan Batik Satrio Manah Kabupaten Tulungagung dengan dengan taraf signifikan $0,000<0,05$.

Hasil penelitian ini hampir sama dengan studi yang dilakukan oleh oleh Christian A.D Selang, bertujuan untuk mengetahui bauran pemasaran (marketing mix) pengaruhnya terhadap loyalitas konsumen pada fresh mart bahu mall manado, faktornya terdiri dari produk, harga, promosi dan distribusi, yang didalamnya akan menentukan tingkat keberhasilan pemasaran dan semua itu ditujukan untuk mendapatkan respon yang diinginkan dari pasar sasaran, faktor Bauran pemasaran adalah faktor yang dianggap penting karena besar kecilnya faktor tersebut otomatis berdampak pada perilaku konsumen dalam memutuskan apakah mau melakukan pembelian atau sebalikny (Mubarok dan Puspitasari, 2010).

c. Pengaruh Marketing Mix (Produk, harga, promosi dan tempat) terhadap keputusan pembelian konsumen di perusahaan Batik Tulungagung yang paling signifikan (Perusahaan Batik Gajah Madadan Perusahaan Batik Satrio Manah) Kabupaten Tulungagung.

Berdasarkan pada hasil penelitian yang peneliti lakukkan dilapangan maka dapat diketahui Hasil Uji t menunjukkan secara parsial pada PB Gajah Mada ada 3 faktor yang mempengaruhi perilaku keputusan pembelian konsumen yaitu faktor Produk, faktor promosi dan faktor Tempat, sedangkan untuk faktor harga tidak mempengaruhi keputusan pembelian konsumen, hal ini dimungkinkan bahwa jika mereka sudah terdesak kebutuhan akan batik, mahal atau murahnya harga sesuai dengan kuantitas dan kualitasnya maka mereka akan membeli, jadi harga tidak menjadi sebuah persoalan bagi konsumen Batik di Kabupaten Tulungagung.

Jadi dari kedua lokasi tersebut antara PB Gajah Mada dan PB Satrio Manah secara Parsial PB Gajah Mada memegang pengaruh yang lebih signifikan dibanding dengan PB Satrio Manah. Alasan lain menurut peneliti yaitu karena banyaknya showroom Batik Gajah Mada inilah yang menjadi satu dari sekian banyak alasan orang akan lebih memutuskan untuk melakukan pembelian di PB Gajah Mada dari PB Satrio manah.

Hasil uji $F$ atau uji simultan menunjukkan nilai signifikansi sebesar 0,000. Baik pada PB Gajah Mada maupun PB Satrio Manah, Karena nilai Sig. $<\alpha(0,05)$ maka $\mathrm{H} 0$ ditolak dan $\mathrm{H} 1$ diterima. Berdasarkan hasil perhitungan statistik maka dapat dikatakan bahwa semua variabel bebas (faktor produk, harga, promosi dan tempat) secara simultan memiliki pengaruh signifikan terhadap keputusan pembelian konsumen pada Perusahaan Batik Tulungagung, baik PB Gajah Mada maupun PB Satrio Manah. Jadi jika keempat faktor ini digabungkan maka akan memiliki dampak signifikan terhadap keputusan pembelian. 


\section{KESIMPULAN}

\section{Kesimpulan}

Berdasarkan data yang diperoleh peneliti mengenai variabel Marking mix terhadap keputusan pembelian konsumen di Perusahaan Batik Tulungagung dapat disimpulkan bahwa: Berdasarkan hasil hasil Uji t pada dua lokasi perusahaan batik tersebut maka dapat diketahui bahwa secara parsial variabel marketing mix pada PB Gajah Mada memberikan pengaruh yang lebih signifikan dibanding dengan PB Satrio Manah, hal itu bisa dilihat dari 3 variabel berbanding 2 variabel antara PB Gajah Mada dan Satrio Manah. sedangkan uji F (simultan) menunjukkan bahwa variabel Produk (X1), Harga (X2), Promosi (X3), dan Tempat (X4) secara bersama-sama mempunyai pengaruh yang signifikan keputusan pembelian pada Perusahaan Batik seperti pada hipotesis kelima. Hal tersebut menunjukkan bahwa faktor Produk, Harga, Promosi dan Tempat merupakan faktor yang menjadi pertimbangan bagi konsumen sebelum melakukan pembelian.

\section{Saran}

a. Bagi Perusahaan Batik di Tulungagung hendaknya lebih gencar melakukan sosialisasi terkait adanya Perusahaan Batik di Tulungagung, dimana batik Tulungagung memiliki ciri khas tertentu dibanding dengan perusahaan batik lainnya. Selain itu perluasan dan segmentasi pasar juga penting karena dengan kita mengetahui siapa pasar kita serta lebih luas otomatis orang akan berbondong-bondong untuk melakukan pembelian.

b. Perusahaan Batik Tulungagung dapat melakukan pendekatan-pendekatan kepada masyarakat terutama konsumen yang kurang begitu memahami arti filosofi dari batik, bahwa batik adalah ciri khas bangsa Indonesia, melalui pendekatan yang informatif maupun penyediaan lokasi showroom kecil sehingga perusahaan batik Tulungagung tidak hanya diterima dan diminati oleh orang-orang golongan atas tetapi seluruh lapisan masyarakat.

\section{DAFTAR PUSTAKA}

----------, 2006. Statistik Untuk Penelitian, Bandug: Alfabeta

---------, 2008. Metode Penelitian Kuantitatif Kualitatif Dan R\&D,Bandung: Alfabeta

Angipora, Marius P., 1999. Dasar-Dasar Pemasaran, Jakarta: PT Raja Grafindo Persada

Arikunto, Suharsimi, 2002. Prosedur Penelitian Suatu Pendekatan Praktek, Jakarta: Rineka Cipta

Bungin, Burhan, 2008. Metode Penelitian Kuantitatif, Jakarta: Kencana

Gunawan, Sudarmanto, R. 2005, Analisis Regresi Linear berganda dengan SPSS, Yogyakarta: Graha Ilmu 
92 MODERNISASI, Volume 11, Nomor 2, Juni 2015

Hadi, Sutrisno, 1987. Metodologi Research I. Yogyakarta: YPFP UGM

http://expertise.hec.ca/chair entrepreneurship/wp-content/uploads/2008-

03Defining the-Entrepreneur-Complexity-and-Multi-Dimensional-SystemsSome Reflections.pdf.Diakses tanggal 12 Juli 2014.

Kasmir, 2004. Pemasaran Bank, Jakarta : Prenada Media

Kerin, Roger A., et.al, 2004. Marketing: The Core, New York: McGraw-Hill

Kotler, Philip, 2004. Manajemen Pemasaran, Jakarta: PT. Indeks

Lamb, Charles W., et.al, 2001. Pemasaran, terj. David Octarevia, Jakarta: Salemba Empat

Mubarak, Mumuh Mulyana dan Ratih Puspitasari, 2010. Mengukur Keputusan Nasabah Melalui Analisis Brand Association (Studi Kasus pada Bank Muamalat Indonesia- cabang Bogor), Jurnal Ilmiah Ranggagading Volume 10 No. $1,45-55$

Murshid, M., 2006. Manajeman Pemasaran, Jakarta: PT. Bumi Aksara

Papavassilio, Nikolas K., 2012. The involvement model in advertising consumer product abroad, (Athens graduate school of economics and bisnis science), European journal of marketing, Vol. 23,No. 1.

Rianto, Nur, 2012. Dasar-dasar Pemasaran Bank Syariah, Bandung: Alfabeta.

Selang, Christian A.D, 2013. Pengaruh Bauran Pemasaran (Marketing Mix) Pengaruhnya TerhadapLoyalitas Konsumen Pada Fresh Mart Bahu Mall Manado, Fakultas Ekonomi Jurusan Manajemen Universitas Sam Ratulangi Manado, ISSN 2303-1174. Jurnal EMBA 71 Vol.1 No.3, Hal.71-80.

Sugiono, 1999. Metode Penelitian Bisnis, Bandung: Alfabeta

Sukotjo, Hendri dan Sumanto Radix A, 2010. Analisa Marketing Mix-7P (Produk, Price, Promotion, Place, Partisipant, Process, dan Physical Evidence) terhadap Keputusan Pembelian Produk Klinik Kecantikan Teta di Surabaya, Jurnal Mitra Ekonomi dan Manajemen Bisnis, Vol.1, No. 2, 216-228.

Sunyoto, Danang, Analisis Regresi dan Uji Hipotesis, Yogyakarta: MedPress,

Swasta, Basu, 2000. Asas-Asas Marketing, Yogyakarta: liberti Offset

Sudarmanto, R. Gunawan, 2005. Analisis Regresi Linear berganda dengan SPSS, Yogyakarta: Graha Ilmu.

Yulianto, Firman, et.al, 2001. Analisis Pengaruh Faktor Bauran Pemasaran Terhadap Pertimbangan Nasabah Dalam Memilih Bank Syariah di Kota Medan, Jurnal Wacana, Vol.13 No.4. 